Father Figures 
Digitized by the Internet Archive in 2018 with funding from

The Arcadia Fund

https://archive.org/details/fatherfiguresgen00frec 


\section{Father Figures}

GENEALOGY AND

NARRATIVE STRUCTURE

IN RABELAIS

\section{Carla Freccero}

Cornell University Press

ITHACA AND LONDON 
Copyright (C) 199i by Cornell University

All rights reserved. Except for brief quotations in a review, this book, or parts thereof, must not be reproduced in any form without permission in writing from the publisher. For information, address Cornell University Press, 124 Roberts Place, Ithaca, New York 14850.

First published 1991 by Cornell University Press.

International Standard Book Number o-8014-2554-9

Library of Congress Catalog Card Number 90-55728 Printed in the United States of America

Librarians: Library of Congress cataloging information appears on the last page of the book.

(2) The paper in this book meets the minimum requirements of the American National Standard for Information SciencesPermanence of Paper for Printed Library Materials, ANSI Z39.48-1984. 
To my father, precursor poet, and to my mother, who taught me how

to translate empires 
